\title{
陸水学と沿岸海洋学に連関する諸問題
}

宇田道隆

Problems interrelated to limnology and near-shore oceanography

By Michitaka UDA

緒 言

大気中の水分が降水現象を通じて陸水に転じ，そ饥が地下水，河川水として流出し，海 に入り，沿岸水を形成する過程は一般的に表 1 をもつて示し得られる。まず，この降水が 気候学的に変動し，旱ばつや洪水によつて利用し得べき水資源に大きな変動が見られる. 水資源は農業用，工業用，飲食用等において水量のみでなく，その水質が問題であり，そ の含有する有機，無機の成分で利用可能な溶在物質（塩類，重金属等）や生物および残 さ，有害で除去すべき污濁物質の量が問題となる。

1960 年夏ヘルシンキ(フィンランド) で開かれた国際測地地球物理学会におけるシンポ ジウでは特にこの方面の有益な研究調查の結果が発表されたから，これらをもとに沿岸 海洋学との連関を中心として重要な諸問題を検討した*(p. 292 後記参照).

表 1 (LinsLey らによる〔1〕)

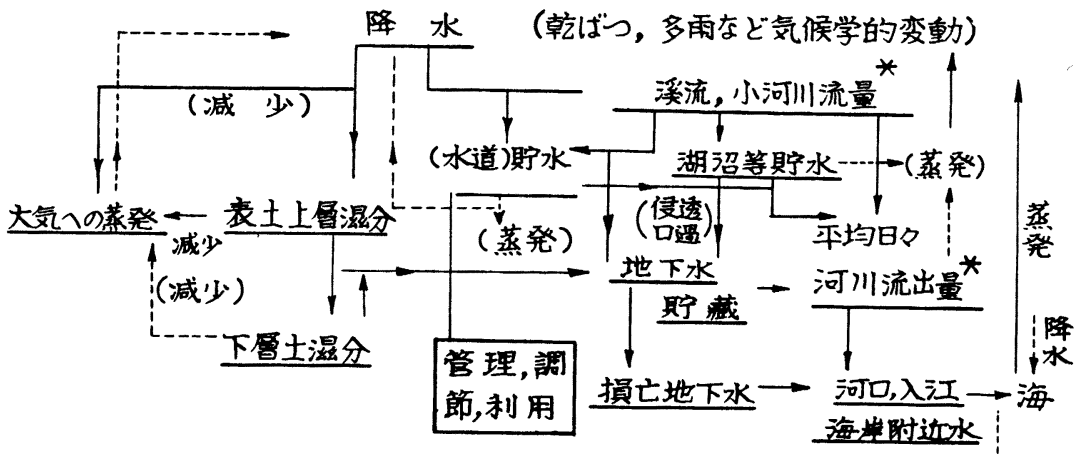

* 總合量は電子計算機により算出。

（混合。拡散。推䅴輸送） 
1. 気候変化による陸水資源の変動

（1）周 期 雨雪等の降水として地球陸上表面に供給される水量注によつて大きな 変化がある. 従つて旱ばつによる湖沼，河川，地下水の低水位と降水量の長年変化を調べ た結果は，すでにBRÜCKNER の周期 30 年にみられるように，平均 30 年前後で典型的に目 立つたサイクルが 20〜50 年とされ，長いのは 35 年以上の周期を示し，短かい 20〜27 年 のはこ机より少く現机る。しかし，ソ連河川流出量にはより短いサイクッ（5９年のも の) が観測されている (A.V. Shnitnikov [2]). スカンヂナビアの湖沼，河川では 9〜15 年 で，太陽活動周期とよく合致する。このような早ばつによる湖沼，河川水位の周期は土地 の性状等により，空間的分布を異にする。

（2）気候学的にみた早ばつの因子 J. NAMIAS 〔3]によれば,夏の早ばつ(例えば 1955 年夏) は中央 (対流圈) 大高気圧とそれに伴う正の気圧偏差に関係する. 北半球で春季に 暖乾天候をおこす大気循環により夏の早ばつが抢こる。この場合，太平洋，大西洋上の夏 の大高気圧の正偏差が大きい。このような気圧分布の変化が早ばつ，従つて陸水資源減少 (湖沼および河川の水位低下がその指標) の原因となる（逆の場合に汸多雨出水に変る）.

（3）その他の因子 R.G. MANN ら〔4〕は最少流量と最も確率の大きい流量の予察方 式をミシシッピー川についてつくつた，河川の流量は気候変化のほかに，田畑の耕作状態 や森林の成長伐採，植林状態など人間の活動による変化も影響する。土䁃の物理，化学的 性状，傾斜面の勾配などの影響はもちろんである。

降雨，気温等，気象変化は高山の雪どけ水流量の好指標となり（FoRsmaN [5])，これ による流量変化の予察資料となる。しかし湖沼，河川の水位は降水に対しあるおくれがあ り，反応時間（response time）がかかる. 反応時間は貯水容量に対する放水量の変化の 比であらわさ机，この值の長いほど流出量変化は少ない（LANGBEIN（6]）.

$\frac{\text { 年流出量変化振幅 }}{\text { 年流入量減少振幅 }}=0.49$ (反応時間 2 年) 0.10 (反応時間 50 年).

\section{2. 河口域の海洋学と陸水の影響}

（1）陸 水 雨雪水の注入によつて海水塩分がうすめられるので，出水の影響は塩分 低極の出現によつてその伝達が沖合に向つて時間的におくれているのを知る（尾鷲湾では 2〜3日）ことができる. 冬、春など低温河川水の注入するときは水温も変化するが，こ の方は普通わずかである。

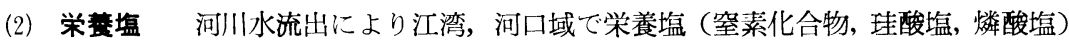
を増すことは，下層からの湧昇水と，ひき入れ (entrainment) が加わるので簡単ではな いが，富栄養化に役立ち，ノリ，カキ，アサリ等増養殖場はもとより，イワシ，エビなど の漁場，生産力に関係する.日本沿岸漁業はもとより，中国の揚子江，黄河等の大河によ 
る東シナ海、黄海，ボッ海などのエビ，底魚等の生産力に関連し重要課題である。プラン クトンの大増殖、赤潮等の関係も興味がある.

（3）河川溶在固形物の流出（DURUM ら〔7〕）高度に管理されたコロラド川を除き， 米国諸河川よりの化学的物質の流出率は， 82 トン/1平方マイル/年 と概算され，西部乾 燥地帯, メキシコ湾平源地方の 34 トン/1 平方マイル/年から湿潤な北大西洋に面する傾 斜地带の 134 トン/1平方マイル/年にまたがる。全体として1年間の河川からの海八運 び出されている化学的物質の流失量は 224.7 (百万) トン，てのうち 55\% ぐらい（123 百万トン) はミシシッピー川からである。そしてメキシコ湾は約 $67 \%$ 索受けとり，太平 洋に約 $21 \%$, 大西洋に約 $12 \%$ はいる。斬領土については (ALEKIN ら〔8]). 溶在塩類 中約 $71 \%$ の（イオン態分子化学的物質の流出が海に達し， 44.5 トン/平方マイル/年で, 年々約 287 (百万トン) のイオン分子的物質が海に流出しており，てのう方 204.56 (百 万トン) は北水洋へはいる。重要なアルカリ金属 (cesium, lithium, rubidium はごく低 濃度）はスペクトログラフで定量分析され，boron, barium, strontium, chromium, copper, lead, titanium 壳検出, 重金属の chromium, copper, nickel, lead は大がいの 河川水域より検出され，一般に濃度 $10 \mu \mathrm{g} / l$ 以下であつた.

表 2 河川よりの全体の\%としてのイオン的化学物質流出の組成

\begin{tabular}{|c|c|c|c|c|c|c|}
\hline 入 海 盤 & $\mathrm{Ca}$ & $\mathrm{Mg}$ & $\mathrm{Na}+\mathrm{K}$ & $\mathrm{CO}_{3}$ & $\mathrm{SO}_{4}$ & $\mathrm{Cl}$ \\
\hline バレンツ海, 白 $\quad$ 海…….......... & 23.6 & 5.2 & 6.1 & 38.0 & 20.3 & 6.8 \\
\hline 黒 海. アゾフ 海........ & 22.1 & 4.4 & 9.4 & 34.6 & 21.1 & 8.4 \\
\hline 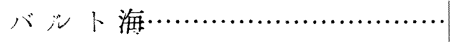 & 24.7 & 6.4 & 3.9 & 51.1 & 8.9 & 5.1 \\
\hline ラプテフ海，チュクチ海……......... & 19.5 & 4.8 & 11.9 & 34.0 & 16.3 & 13.6 \\
\hline ベーリング, オホーツク海, 日本海 & 21.1 & 5.6 & 9.3 & 41.3 & 15.8 & 6.8 \\
\hline
\end{tabular}

註 メーコン川の運ぶ量につき小林 〔9] 注同河口より $1500 \mathrm{~km}$ 上流の Nongkai で 20.5 百万トン/年 と算定した.

以上のように，莫大な流出化学物質の水産上の効果はもとより，工業的資源としての回 収など今後に多くの問題を提供する。また河川の微量な特殊成分が独特の二オイ (smell) を流水に与え，サケ，マスの母川回帰を誘うもとになつているかも知れない.

（4）砂泥堆積 (LINDENER ら〔10]) 感潮河川の口は入江につながり, 成凮型, 完全混 合型，不完全混合型の 3 型が卓越寸る. 二重成風型の下凰塩水が淡水中に河川上流に向つ て楔状に進入する salt water wedge が上層からおちて来る懸濁砂泥粒子をつかまえて， とりこにし，これが砂洲のように底に堆積して浅瀬をつくり，時には下層流にはこばれ て，河川の上手の港などすつかり浅くしてしまい，ドレッジに莫大な経費を投じなけ机ば ならなくした例 (Cooper River〔11’’) もある. 特に日本でも多雨出水季, 台風洪水期に問 
題となる。またダム出水によるブリ定置網漁場に及ぼす影響など論ずるおりには看過でき ない．ニゴリの量の測定，水中照度を河川，河口入汇で鉛直的に調べる必要がある．河口 水域の埋立も，高潮，洪水，浪害，流動変化などが問題になる.

（5）污染水拡散 水質污毒は鉱工業廃水，都市廃水の処理，放射能污染水などに関連 し，今や水産上，衛生上も大問題となつており，河川，浅海内湾で特に激化している. 拡 散についてはタービュレンス（乱流）と共にその混合係数，置換係数などの算定，実測， 実験が要求せられ，プランクトン（珄藻等）や魚卵，稚魚，ベントスなど併せて生物学的 調查も併行的に必要となつている。 アイソトープの $\mathrm{Cr}^{51}$, Scandium 46 など追跡子に用い 調查も行われている. 発光色素, 口ーダミンBなどもよく用いられる(PRITCHARD [11]). 河川と海の浄化こそ焦盾の急である。また，地下水の放射能污染も問題である.

（6）地下水の利用海岸から流失する伏流地下水の算定も重要な課題である. 工業用 水などに地下水の汲揚げが過度のため地盤沈下が年々甚だしくなつているのは大都市工業 地带 (東京, 名古屋，大阪，新潟など）にひとしく因難な問題となつている. 加圧再使用 水の注入還元なども当然考えられよう，また海岸に近いところでは塩水混入のため，水と 塩の分離がイオン交換樹脂筒や，電解法，その他の方法で考えられねね゙ならない．海岸侵 玲や浪害の問題も地船沈下と共に加速的に生活をおびやかす重要さを加える.

$$
\text { 結 び }
$$

河川と海の間に陸水学, 海洋学, 水産学, 工業, 衛生, 交通などの立場から解決を迫ら れている境界域問題が年々増加して来ている。

旱汭つ，洪水による河川と近岸沿海の水量，流速，砂泥運搬，底、動植物，水質などの 変化，特に台風など暴風水害に伴う変化とこれらの予察および防災対策が研究されねばな らない．沿海におよぼす河川出水の生産力への影蠁と積極的な土木事業により漁場，増養 殖場の造成など進めらるべきである．なお流亡化学（鉣物）資源の利用回収も污濁水防止 と一しよに研究をいそぐべきである。これらはすべて陸水学者, 海洋学者. 水産学者, 工 学者などが強力に共同連合して解決に当るべき問題である。

\section{参考文 献}

International Association of Scientific Hydrology. General Assembly of Helsinki. Commission of Surface Waters, Publication No. 51, 1960. 中の下記文献.

1) Linsley, R. K., \& N. H. Crawford (1960): Computation of a synthetic streamflow record on a digital computer. 同上, p. 526 538.

2) Shnitnikov, A. V. (1960): Cyclic regularities of the general moisture supply in the semi-arid zone of the U.S.S.R. 同上, p. 121 122.

3) Namias, J. (1960): Factors in the initiation, perpetuation and termination of drought. 同上, p. 81 94. 
4) Mann, R. G., \& E. M. Rasmusson (1960): Extending lowflow forecasting operations on the Mississippi river. 同上, p. 193 200.

5) Forsman, A. (1960): Effect of air temperature and rainfall on snowmelt runoff. 同上, p. $511 \sim 516$.

6) LANGBEIN, W.B. (1960): Water levels as indicators of longterm precipitation or runoff. 同上, p. 517 525.

7) Durum, W. H., Heides, S. G. \& L. J. Tison (1960): World-wide runoff of dissolved solids. 同上, p. $618 \sim 628$.

8) Alekin, O. A. and L. V. Brazhnikova (1957): New data on the discharge of dissolved substances from the Territory of the USSR. Proc. of the Acad. of th USSR. 114, No. $1 \sim 6$.

9) KовауаSH, J. (1959): Chemical investigation on river waters of Southeastern Asiatic Countries. Berichte des Ohare Instituts für landwirtschaftliche Biologie. 11, Hf. 2. p. 167 233.

10) Lindenner, C. P. (1960): Currents in tidal reaches of rivers and their effect on shoaling of side basins. 同上. p. 290 301.

11) Pritchard, D. W. \& J. H. Carpenter (1960): Measurements of turbulent diffusion in estuarine and inshore waters. 同上, p. 361.

11') The Johns Hopkins University. Chesapeake Bay Inst. Collected Reprints. 1955 56, Vol. 3, p. 436.

* 後記 : 1960 年 7 月 30 日ヘルシンキの国際海洋物理学会 (IAPO) 注, ソ連海洋地質学者 V.P. ZEnkovich, V.V. Longinov の提唱した「沿岸海洋委員会」設立案をとり あげ，8月6日 IUGG 総会で可決した。これは，沿岸水帯，特に波力の及ぶ浅海 水域について，波や流れ等のエネルギーがどのように海陸の境界，海底にはたら いて，陸圈を破壊し，海岸地形や海底を変えるか，主として力学的に研究し，海 岸造築防護，漂砂堆積，港湾，海岸採鉱 (砂鉄等)，近岸動植物への影響等を問 題とする. 特に暴風時の港の変化, 水と砂泥岸石片の運動変位, 波による流れと その非対称性, 浅海潮汐力学と塩水進入による河口水域の土砂堆積の物理的機構 等が問題とされる.

\section{S U M M A R Y}

Reviews on the cyclic fluctuation of land water level due to drought, transport of dissolved chemical substances, sedimentation in river and estuary \&c with some discussions were presented. Boundary problems linked to limnology and oceanography are stressed. 